\title{
The Correlation of Leg Muscle Power and Speed Towards Shooting Ability in Football Game at U15 SSB Riau University
}

\author{
W D Saputra ${ }^{1 *}$, Ramadi $^{1}$, A Juita ${ }^{1}$ \\ ${ }^{1}$ Faculty of Teacher Training and Education, Universitas Riau, Indonesia \\ "Corresponding author. Email: wandidedi07@gmail.com
}

\begin{abstract}
This research was conducted to know and determine any correlation between leg muscle strength and speed to the shooting capability in football players SSB U15 university of riau. Kinds of this research is a correlation with involving 20 people's while the sampling technique used was total sampling. From the calculation that is know that there is a significant relationship between the variables X1, X2 and Y correlation leg muscle strength to the shooting abililty of football players SSB U15 university of riau. The result obtained from the correlation calculation was rvalue $=, 631$ while $\mathrm{r}$ table $=0.456$. It means rvalue $0,630>$ rtable $(0,456)$ or there is any correlation between leg muscle strength and speed to the shooting capability in football player SSB U15 at the university of Riau.
\end{abstract}

Keywords: Leg muscle power, shooting ability, football game

\section{INTRODUCTION}

Football is a very popular sport among the public at large is no exception of indonesia. This can be seen by the large number of society both men and woman to the football field. The arrival of the society described how the magnitude of the interests of the community against the sport of football. Although the each have different reasons, some come to play just fill in spare time, improve the skills of even just want to watch the football game. but these things to improve skills play football, it is a thing that is not easy to come by and controlled, if not through the process of practicing the coaching and guided by a coach.

For that in the game of football, a player claimed to have a good mastery of the basic technique, because it is the main requirement for being a quality player and has a high skill in the game of football. It is like the opinion of jefsneyes (2008) that in sports the very factors determine the football success one squad is a mastery of basic techniques " as for the basic techniques in the game of football are as follows: 1) kick ball 2) received the ball 3) heading the ball, dribble) 4. 5) motion of a trick with the ball. 6) seized the ball. 7) throwing the ball. 8) techniques.

The purpose of football games, according to eric. C batty (2007) was scored as the number to my opponent. " Thus all the players must be able to route the individual action, because it's not just the players who have to do a assailant attacks, but midfielder and back also need to skillfully do individual action for strike to the area the opposing defense. Because in modern football games, Defender also has a duty and a responsibility to join the assault so that creation of a goal. in creating a goal in need also a good physical condition. In principle if we affect a game the sepkbola components of physical condition that we can use in conducting shooting in the game of football is a. Power, agility and stamina, there are several components of the physical conditions in the pass by sajoto (1990) including "power (strength) endurance (endurance) yield (power) velocity (speed) of power supple (flexibility), agility (agility) Coordination ( koordination) balance (balance) accuracy (accuracy) and reaction (reaction).

The main purpose is the goal in a football game, therefore the study will examine the factors that affect the ability of the scoring in the game of football. There were several factors that influenced them among them are the strength of limb muscles. If a player has a strong limb muscle strength means it will increasingly have the opportunity to score better than those who have less muscle strength leg muscle power limbs. is the ability of limb muscles feet in accepting the burden while working. Limbs provide balance in the body when will administer the shots, also giving a strong impulse at the time of the shot.

Other factors that affect the ability of the results of the shooting is running speed. running speed is a factor in determine the speed of the shot into the goal. To increase power at the time of scoring, in need of 
exercise strengthens the muscles. In the event of sports competition a maximum achievement (suharno: 2002) the sooner a football player running indicates that he will be increasingly able to print results kick faster and can not be stopped.

\section{METHOD}

This research was planned to be carried out on the football field SSB Riau University u. Time Research July - September 2015. The research was done by using the correlational research design and included into causal relationships i.e. causal relations are aiming to find out the extent of the relationship between free variables i.e. muscle strength limb and speed and variable

The population in this research is a football school (SSB) the University of Riau's U-15 totalling 20 people. All population was taken as the sample since it is less than 100 people.

Data taken in this research was conducted directly by applying the tests in accordance with the research instrument. There are three types of data that the researcher take. First data is data the strength of limb muscles by using a measurement tool called leg dynamometer. The second data is data speed. This data is obtained by applying a test run. The third data is data about shooting ability using tests of targeting the ball.

After the data in each variable obtained at one of the test results, the next step is to process the data using a statistical formula. How to find out or no relationship between the strength of the limb muscles and speed with the capability of shooting on SSB Riau University U-15

Based on the hypothesis put forward in the study, the data analysis techniques in use is a correlation analysis shows how far the relationship the relationship between variables (X 1) and (X 2) and variable (Y). The result of the calculation of the correlation is called with the koofisien correlation was developed with the letter (r). Next the koofesien correlation index ranges from-1 to 1 . Whereas to test the third hypothesis, tis study used using the multiple correlation formula:

To reject or accept the hypothesis, it was based on these provisions: "if $r$ count is smaller than $r$ table $(\mathrm{rh}<\mathrm{rt})$, then Ho is accepted and $\mathrm{Ha}$ is rejected. But conversely if $r$ count is greater than $r$ table $(r h>r h)$ then Ha is accepted (sugiyono, 2012). Because the sample taken is the total number of populations, the significance does not need to be tested is rejected then $\mathrm{Ha}$ is accepted if rcount $>$ rtable

To find out the level of relationship of the value of $r$, the following table presents the interpretation of the correlation coefficient Value $r$.

\section{RESULTS AND DISCUSSION}

Description of the data of this research consists of three variables, namely the free variables of limb muscles strength ( $\mathrm{X}$ 1), speed (X 2) and a bound variable ability in doing the shooting (Y). Description of data from each of these variables can be expressed as follows.

\section{Data On Leg Muscle Strength Test Results (X1)}

Data gained from the variable strength of limb muscles (X 1) in measure using a leg dynamometer tests on follow by the sample as many as 20 people, once in the specified frequency for each data then you can conclude the score $($ mean $)=53.80$ variant $=94,81$ standard the is a 9.737. For clarity the dissemination of score this limb muscle strength can be seen in table 3 below.

Table 1. Leg Muscle Strength Data.

\begin{tabular}{|l|c|c|c|}
\hline No & $\begin{array}{l}\text { Interval } \\
\text { Class }\end{array}$ & Frequency & $\begin{array}{l}\text { Relative } \\
\text { Frequency (\%) }\end{array}$ \\
\hline 1 & $40-45$ & 4 & 20 \\
\hline 2 & $46-51$ & 4 & 20 \\
\hline 3 & $52-57$ & 5 & 25 \\
\hline 4 & $58-63$ & 0 & 0 \\
\hline 5 & $64-69$ & 7 & 35 \\
\hline \multicolumn{2}{|l|}{ Jumlah } & 20 & 100 \\
\hline
\end{tabular}

Based on table 3, out of 20 samples in class 40-45 interval classes there are 4 people with a percentage of $20 \%$, in interval classes 46-51 there are 4 people with a percentage of $20 \%$, in the 52-52 interval class there are 5 people with a percentage of $25 \%$, in the 58-63 interval class there are 0 people with a percentage of $0 \%$, in the 64-69 interval class there are 7 people with a percentage of $35 \%$.

\section{Data Of The Speed Test Result (X2)}

Based on table 3, from 20 samples in the class interval class $40-45$ there are 4 people with the percentage of $20 \%$, on the class interval 46-51 there are 4 people with the percentage of $20 \%$, on the class interval 52-52 there are 5 people with the percentage of $25 \%$, on a class of interval 58-63 There are 0 people with percentage of $0 \%$, on a class interval 64-69 there are 7 people with the percentage of $35 \%$.

Table 2. Speed Test Result Data

\begin{tabular}{|l|l|l|l|}
\hline No & Interval Class & Frequency & $\begin{array}{l}\text { Relative } \\
\text { Frequency( } \\
\%)\end{array}$ \\
\hline 1 & $7,11-7,47$ & 5 & 25 \\
\hline 2 & $7,48-7,83$ & 2 & 10 \\
\hline 3 & $7,84-8,20$ & 4 & 20 \\
\hline 4 & $8,21-8,56$ & 6 & 30 \\
\hline 5 & $8,57-8,9$ & 3 & 15 \\
\hline \multicolumn{2}{|l|}{ Total } & 20 & 100 \\
\hline
\end{tabular}


Based on table 4, the frequency distribution resulting from the speed of 20 samples is 5 people $(25 \%)$ who have interval scores of $7.11-7.47$. There are 2 people $(10 \%)$ who have an interval score of 7,48 7,83 . There are 4 people $(20 \%)$ who have an interval score of $7.84-8.20$, there are 6 people $(30 \%)$ who have an interval score of $8.21-8.56$. There are 3 people (15\%) who have interval scores from 8.57 to 8.9 .

Data on the Shooting test results (Y)

Data gained from the shooting ability variable (Y) in measure with tests shooting at the ball in a follow by as many as 20 people sample. Once in the specified frequency for each data then you can conclude the results of the average (mean) $69=82.8$ variants, standard deviation is 9.099451 .

Table 3. Shooting test results data

\begin{tabular}{|l|l|l|l|}
\hline No & $\begin{array}{l}\text { Interval } \\
\text { Class }\end{array}$ & Frequency & $\begin{array}{l}\text { Relative } \\
\text { Frequenc } \\
(\%)\end{array}$ \\
\hline 1 & $7,11-7,47$ & 5 & 25 \\
\hline 2 & $7,48-7,83$ & 2 & 10 \\
\hline 3 & $7,84-8,20$ & 4 & 20 \\
\hline 4 & $8,21-8,56$ & 6 & 30 \\
\hline 5 & $8,57-8,9$ & 3 & 15 \\
\hline Total & & 20 & 100 \\
\hline
\end{tabular}

Based on table 5 frequency distribution capability of shooting, of 20 samples contained 7 people $(35 \%)$ who have a score interval $57-61$. There are 0 people $(0 \%)$ Who has a score interval $62-66$. There are 4 people (20\%) who have the score $67-71$. There are 7 people $(35 \%)$ who have a score interval $72-76$. There are 2 people $(10 \%)$ that have a score interval $77-81$.

\section{Data Analysis}

Before the data in the analysis of the first test was conducted it was prior to be tested its normality through liliefors Test. then proceed with determining the $r$ of each variable with variable $\mathrm{Y}, \mathrm{X} 1$ and $\mathrm{X} 2$ with $\mathrm{Y}$ done using correlation analysis product moment. To find out whether connected or data by comparing the value of $r$ count or value correlation product moment with $\mathrm{r}$ table, whereas to determine the value of $R$ variables $X 1$ and $\mathrm{X} 2$ with $\mathrm{Y}$ done using binary correlation formula, further count compared to the value of $\mathrm{R} \mathrm{r}$ table to find out related data or not. Because the sample is the sum of the overall population then it is no longer necessary to put to the test of significance.

\section{Normality}

Testing normality is an analysis that was conducted to test whether the data comes from a Gaussian population or not. This test is done to find out more if the data on the correlation technique can be used though. Testing the normality of the data in the test by analysis of liliefors on a significant level $\alpha=0.05$ basic decision-making testing normality is. When Lomaks $<$ ltabel then the samples come from Gaussian populations. Conclusion the results of the test of normality can be seen in table 6 below

Table. Summary of normality tests of leg muscle explosive power variables and speed of shooting ability

Table 4. Normality

\begin{tabular}{|c|c|c|c|c|}
\hline No & Variable & $\begin{array}{c}\text { Lotabel< } \\
\text { Ltabel }\end{array}$ & \multicolumn{2}{|c|}{ Conclusiom } \\
\hline 1 & $\begin{array}{c}\text { Leg Muscle } \\
\text { Power }\end{array}$ & 0,166 & 0,190 & Normal \\
\hline 2 & Speed & 0,185 & 0,190 & Normal \\
\hline 3 & $\begin{array}{c}\text { Shooting } \\
\text { Ability }\end{array}$ & 0,160 & 0,190 & Normal \\
\hline
\end{tabular}

Information:

Lomax: the biggest absolute price difference is between the standard score opportunity with a smaller proportion of the raw score or the standard score being calculated.

Ltabel: The critical value of the liliefors test

Based on the table above, variable leg muscle explosive power (X1) at a significant level of 0.05 was obtained Lomaks 0.166 <Ltable 0.190 varaibel speed (X2) at a significant level of 0.05 obtained Lomax 0.185 < Ltable 0.190 and variable shooting ability (Y) obtained Lomaks 0.160 <Lable 0.190. At a significant level of 0.05 if Lomax is smaller than Ltabel means pupulation is normally distributed.

Correlation analysis

Based on the results of the analysis of the correlation of limb muscle power (X 1) against traffic shootiong (Y) of the correlation coefficients obtained by $\mathrm{r} 1=0.631$, then an analysis of the correlation of velocity (X 2) against kempuan shooting (Y) on the correlation coefficient $\mathrm{r} 2=$ earn 0.630 , next to the double variable correlation analysis results X 1 and X 2 against shooting ability obtained correlation $\mathrm{R}=0.891$. To know such data relate or not is to compare in each $r$ count ( $\mathrm{r} 1 \mathrm{r} 2$ and $\mathrm{R}$ ) and $\mathrm{r}$ chart with $\alpha$ and $0.05 \mathrm{~N}$ (total sample) $=20$ at $0.456=$ rtabel earn and the result is rhitung (r1 r2 and $\mathrm{R}$ are respectively) rtabel> and based on table 2, correlation coefficient $r$ Value interpretation (Riduan and Sunarto, 2011:81), then by using the chart interpretation ties the variables $\mathrm{X} 1$, $\mathrm{x} 2$ with $\mathrm{Y}$ with $\mathrm{Y}$, and $X \quad 1$ and $X \quad 2$ together with the variable $Y$ relationship interprestasinya categorized strong 
Table 5. Correlation Significance Test X1, X2 With Y.

\begin{tabular}{|l|l|l|l|}
\hline $\begin{array}{l}\text { Correlation } \\
\text { Between }\end{array}$ & Value & \multicolumn{2}{|l|}{ Conclusion } \\
\hline X1 and Y & r. hitung $=$ & $\begin{array}{l}\text { rtabel } \\
0,631\end{array}$ & $\begin{array}{l}\text { Signifika } \\
\text { n }\end{array}$ \\
\hline X2 and Y & $\begin{array}{l}\text { r. counted }= \\
0,630\end{array}$ & Significant \\
\hline X1 and X2 and & R counted $=$ & Significant \\
Y & 0,891 & \\
\hline
\end{tabular}

Relationship Of Strength Of Limb Muscles Against Shooting Capabilities

Power is the ability of the muscle to resolve prisoner or load in the running activity. muscle strength that in produce by the muscles in the limb is used to drive away swing from back to front in the angular with the aim of kicking the ball. from the angular motion is strong, when touching an object then the object (ball) will move forward in accordance with the magnitude of the style of encouragement. More power on have the greater the performance also in doing. The strength of its own influence on the results of a backlash towards the goal. If kick doesn't have the strength not likely going to happen and kicks that have strong concentration resulting in the right kick, because the kick has to be supported by the strength of limb muscles, because of the strength limb muscles sped the ball so hard and precise. The strength of limb muscles have an effect on the power and accuracy of the kick, if no power is unlikely to be ball's pace toward the goal. For ball players certainly should pay attention to the technique of kicking the ball in order to get a hard kick right and toward the goal.

The strength of the limb muscles getting bigger football players showed that the stronger their muscles in kicking so that would further increase the number of results the kicks on football player. Berrorientasi on the strength analysis of limb muscles have an influence on the results of a backlash towards the goal.

The Relationship Of Speed Against The Ability Of Shooting

Speed is a person's ability to perform a series of motion or the motion as soon as possible in response to stimulation. In other words, the speed of a person's ability to respond to stimulation with a form of motion or series of motion in time as soon as possible. On their sports some sort of running, swimming and so on the achievements in the measure is the speed (the shortest time/short on getting to reach a certain distance.

Running speed related to the results of a backlash towards the goal. When the higher running speed, it will increase the power kicks in when kicking the ball towards the goal, thereby increasing the chances of a successfulkick towards goal. The analysis of oriented then it can be said there is a relationship of speed against the ability of shooting.

The Relationship Of Muscle Strength Limb And Speed Against The Ability Of Shooting

Kicking the ball in football games is in do to achieve the goal and kicking the ball when all physical conditions play an active role. The combination of aantara strength of limb muscles, running speed will effect the results of taking action against big kicks towards the goal. Each has its own function, muscle strength of unequal strength against kicks the ball that hard to produce maximum power. Speed plays a role to improve the results the rigors of the speed of the ball towards the goal,

The strength of the limb muscles getting bigger football players showed that the stronger their muscles in menedang so that it will further improve the number of results the kicks on football player. A faster run speed again will increase the power that exploded at a time when kicking the ball towards the goal, thereby increasing the chances of a successful kick towards goal. the more precise the kick it will be getting bigger or more the result of the kicks on football player.

\section{CONCLUSION}

Based on the results of research and data processing using procedures satistik research then inferredthat; 1 ) There is a relationship between variables $\mathrm{X} 1$ and $\mathrm{Y}$ $(0,631)$. Meaning (Ha accepted); 2) There is a relationship between variables X2 with $\mathrm{Y}(0,630)$. Meaning ( $\mathrm{Ha}$ is accepted); 3) There is a joint relationship between variables $\mathrm{X} 1$ and $\mathrm{X} 2$ with $\mathrm{Y}$ (0.891), meaning ( $\mathrm{Ha}$ is accepted). Based on the description above, that leg muscle strength and speed have a relationship with shooting ability, the researcher proposes the following suggestions: 1) There is a relationship between variables X 1 with $\mathrm{Y}(0.631)$. Does that mean (Ha received); 2) There is a relationship between the variable X 2 with Y (0.630). Does that mean (Ha on receipt); 3) There is a relationship between the variables together $\mathrm{X} 1$ and $\mathrm{X} 2$ with $\mathrm{Y}$ (0.891), meaning (Ha on receipt)

\section{REFERENCES}

[1] Arikunto, suharsimi. (2006). prosedur penelitian suatu pendekatan praktik. Jakarta

[2] Arsil. (2000). Pembinaakondisi Fisik. Padang

[3] Drs, Syaifudin, B.AC. (1992) Anatomi fisiologi : penerbit buku kedokteran

[4] Engkos kosasih . (1993 ) panduan teknik-teknik melatih. Bandung

[5] Ismaryati . (2008 ) tes dan pengukuran olahraga, surakarta

[6] Muhajir. (2006: 4) pendidikan Jasmani Teori dan Praktik 1, Jakarta

[7] Mielky. (2007) dasar-dasar sepak bola. Bandung 
[8] Nurhasan (2001: 162) Tes dan pengukuran dalam pendidikan jasmani, Jakarta,

[9] Muhyi Faruq. (2008) meningkatkan kebugaran jasmani. Surabaya,

[10] Sucipto ,dkk. (2007) sepakbola, Depdiknas,

[11] Soekatamsi. (1999) permainan bola besar (sepakbola). Dediknas. Jakarta

[12] Sugiyono. StatistikadanPenelitian. Alfabeta: Bandung.

[13] Sajoto. (1995). Peningkatan dan pembinaan kekuatan kondisi fisik dalam olahraga. Edisi revisi: Semarang

[14] Winarno. (2006). Pengembangan permainan sepaktakraw. Center for human capacity development: Malang

[15] Zulfan Ritonga. (2007) statistik. klaten sakamitra kompetensi. 